\title{
Population dynamics of house mice without mammalian predators and competitors
}

\author{
Deborah J. Wilson ${ }^{1 *}$, John G. Innes ${ }^{2}$, Neil B. Fitzgerald ${ }^{2}$, Scott Bartlam² ${ }^{2}$ Corinne Watts ${ }^{2}$ and \\ Mark C. Smale ${ }^{2}$ \\ ${ }^{1}$ Manaaki Whenua - Landcare Research, Private Bag 1930, Dunedin 9054, New Zealand \\ ${ }^{2}$ Manaaki Whenua - Landcare Research, Private Bag 3127, Hamilton 3240, New Zealand \\ *Author for correspondence (Email: wilsond@landcareresearch.co.nz)
}

Published online: 22 May 2018

\begin{abstract}
Mesopredator and competitor release can lead to population increases of invasive house mice (Mus musculus) after larger introduced mammals are controlled or eradicated. In New Zealand, mammal-resistant fences have enabled multi-species mammal eradications in order to protect indigenous species. When house mice are the only mammals remaining in these biodiversity sanctuaries, they may reach a high population density, with potential consequences for their indigenous prey. We studied mouse populations in the absence of other mammals for 5 years at mammal-resistant fenced forest sites at Maungatautari, Waikato. We used spatially explicit capture-recapture (SECR) to estimate mouse population density quarterly in two independently fenced sites, with contrasting levels of mouse management that were switched half-way through the study. In the absence of mouse control, mouse population density reached $30-46 \mathrm{ha}^{-1}$ at one site each year after summer breeding, and $23 \mathrm{ha}^{-1}$ at the other site. Mouse tracking rates in inked footprint tunnels were positively related to numbers of mice captured in each session, but not significantly to mouse density. The highest mouse densities were similar to estimates in New Zealand forest and alpine ecosystems after mass seeding (masting) events, but lower than estimates in another sanctuary and on some islands lacking larger terrestrial mammals. We suggest that in the absence of competition and predation from other mammals, food limitation may have prevented mouse populations from attaining very high densities in this mainland forest location.
\end{abstract}

Keywords: biodiversity sanctuary; competitor release; food limitation; invasive species; island; mesopredator release; Mus musculus; New Zealand; population density; SECR

\section{Introduction}

Species introduced into an ecosystem are often managed by eradication or population reduction to protect indigenous flora and fauna (Myers et al. 2000; Courchamp et al. 2003; Smith et al. 2010). However, trophic or competitive interactions can cause non-target introduced species to respond numerically to these control programmes, inflicting additional or greater ecosystem damage (Zavaleta et al 2001; Courchamp et al.2003). Removing a top predator can lead to increased abundance of smaller predators (mesopredator release; Soulé et al. 1988; Courchamp et al. 1999; Ritchie et al. 2012). Removing a competing species can lead to increased abundance of its inferior competitor, which benefits from reduced interference and/or greater access to shared resources (competitor release; Caut et al. 2007; Trewby et al. 2008; Ruscoe et al. 2011). Both of these ecological release mechanisms can result in increased predation on indigenous taxa in the managed ecosystem (e.g. Rayner et al. 2007; Ritchie \& Johnson 2009; Norbury et al. 2013).

House mice (Mus musculus) are among the world's most prevalent invasive mammals, owing to their potentially rapid population growth, flexible omnivorous diet, and long association with humans (Bronson 1979; Auffray et al. 1990; Ruscoe \& Murphy 2005). Wild, non-commensal house mice are usually uncommon and inconspicuous in ecosystems where larger mammals are present (Bronson 1979; Angel et al. 2009; Harper \& Cabrera 2010). However, they become abundant on oceanic islands and the New Zealand mainland when their mammalian competitors and predators are absent or removed (e.g. Innes et al. 1995; Choquenot \& Ruscoe 2000;
Jones et al. 2003; Witmer et al. 2007). In turn, predation by abundant mice on oceanic islands lacking other terrestrial mammals can significantly affect indigenous biota (Angel et al. 2009; Simberloff 2009). Mice also become numerous when food is plentiful (King 1983; Wilson \& Lee 2010). Extensive mouse plagues in the wheat-growing areas of south-eastern Australia follow rainfall and other possible prerequisites, such as reduced rates of predation and disease (Pech et al. 1999; Krebs et al. 2004; Singleton et al. 2007).

As these examples suggest, multiple factors may combine to limit mouse population size. Norbury et al. (2013) demonstrated mouse population growth after experimental predator removal, but only where grass seed provided ample food for mice. Other studies have attributed mouse population increases to relaxation of interference and/or exploitative competition after removal of ship rats (Rattus rattus) (e.g. Brown et al. 1996; Witmer et al. 2007; Harper \& Cabrera 2010; Ruscoe et al. 2011) or Norway rats (Rattus norvegicus) (Ji et al. 1999; cf. Tennyson \& Taylor 1999). However, as both ship rats (McQueen \& Lawrence 2008; Bridgman et al. 2013) and Norway rats (O'Boyle 1974) may also prey on mice, competitor and mesopredator release combined may have caused these mouse population increases.

In New Zealand, house mice are the smallest of the mammalian species introduced since humans arrived in c. 1280 $\mathrm{AD}$, when bats were the only terrestrial mammals (King 2005; Wilmshurst et al. 2008). Mice had reached New Zealand on European ships by the 1820s (King 2016) and they are now present in most habitats throughout the country (Ruscoe \& Murphy 2005). They prey primarily on seeds and invertebrates (Ruscoe \& Murphy 2005), and sometimes also on lizards 
(Newman 1994; Norbury et al. 2014) and the eggs and chicks of birds (Cuthbert \& Hilton 2004; O’Donnell et al. 2017). Biodiversity sanctuaries have been established to protect native species on the New Zealand mainland by removing invasive mammals and excluding them with mammal-resistant fences (Innes et al. 2012). In addition to ship rats and Norway rats (discussed above), other mammals that are removed and excluded are predators of mice - cat (Felis catus) and the mustelids stoat (Mustela erminea), ferret (Mustela putorius) and weasel (Mustela nivalis) - and a potential competitor (hedgehog, Erinaceus europaeus). Removal of most species is usually successful, but mice either survive eradication attempts or subsequently reinvade (Innes et al. 2012) through small openings in or under the fence. Hence, these mice occupy environments with reduced predation and interspecific competition.

We studied the population dynamics of house mice for 5 years in the absence of other introduced mammals within mammal-resistant fences at a forested biodiversity sanctuary. We compared mouse population densities between two independently fenced sites, with contrasting levels of mouse management that were switched half-way through the study. We also assessed mouse demographic parameters (body condition, body size and reproductive condition) that could be affected by differences between sites and management treatments, and could help to explain density variation.

\section{Methods}

\section{Study site}

Maungatautari is an extinct andesitic volcano in the Waikato region, North Island, New Zealand. Lowland forest on Maungatautari below $600 \mathrm{~m}$ a.s.l. is dominated by tawa (Beilschmiedia tawa) with frequent mangeao (Litsea calicaris) and kāmahi (Weinmannia racemosa), and above $600 \mathrm{~m}$ by tawa and kāmahi, with scattered rimu (Dacrydium cupressinum) and tāwari (Ixerba brexioides) (Nicholls 1967).
The Maungatautari Ecological Island Trust (MEIT) enclosed Maungatautari with a mammal-resistant fence (Day \& MacGibbon 2007) in August 2006 (Table 1). Most pest mammals were eradicated inside the fence in a prolonged operation that started in November 2006 (Speedy et al. 2007). Mice became very scarce but were probably never eradicated entirely from the reserve. Since February 2012 no further mouse control was attempted, and mice became increasingly abundant.

An independent mammal-resistant fence was built in 2006 around a 17 ha private forest block, covenanted to the Queen Elizabeth II National Trust and separated from the main Maungatautari reserve by a vehicle track. Mammals were eradicated from this block during the next 2 years, but mice apparently reinvaded and had become abundant again by 2011 (Table 1).

Our study began in April 2011 at two independently fenced sites (Fig. 1) with contrasting levels of mouse management. Our Q block study site, the 17 ha independently fenced private forest block described above, had no mouse control and high mouse density at the beginning of the study. Our 24 ha M block (100 $\mathrm{m}$ north of $\mathrm{Q}$ block), received ongoing mouse control as part of the main fenced 3400 ha reserve; mice were undetectable there when this study began. Each site resembles a peninsula of forest partially surrounded by farmland (Fig. 1).

Midway through our study, in August 2013, we switched mouse management treatments between the two blocks, to assess experimentally how mouse abundance levels affect indigenous biota, in a related study (Watts et al. 2017). MEIT eradicated mice from $\mathrm{Q}$ block, and in $\mathrm{M}$ block the remaining mouse control was withdrawn (Table 1) and the mouse population was allowed to increase. Mouse population density in Q block was high from April 2011 to August 2013, and low from November 2013 to February 2016. We refer to these block-phase combinations as QH and QL, respectively. In contrast, mouse density in M block was low and then higher $(\mathrm{ML}$ and $\mathrm{MH})$ in the same respective periods.
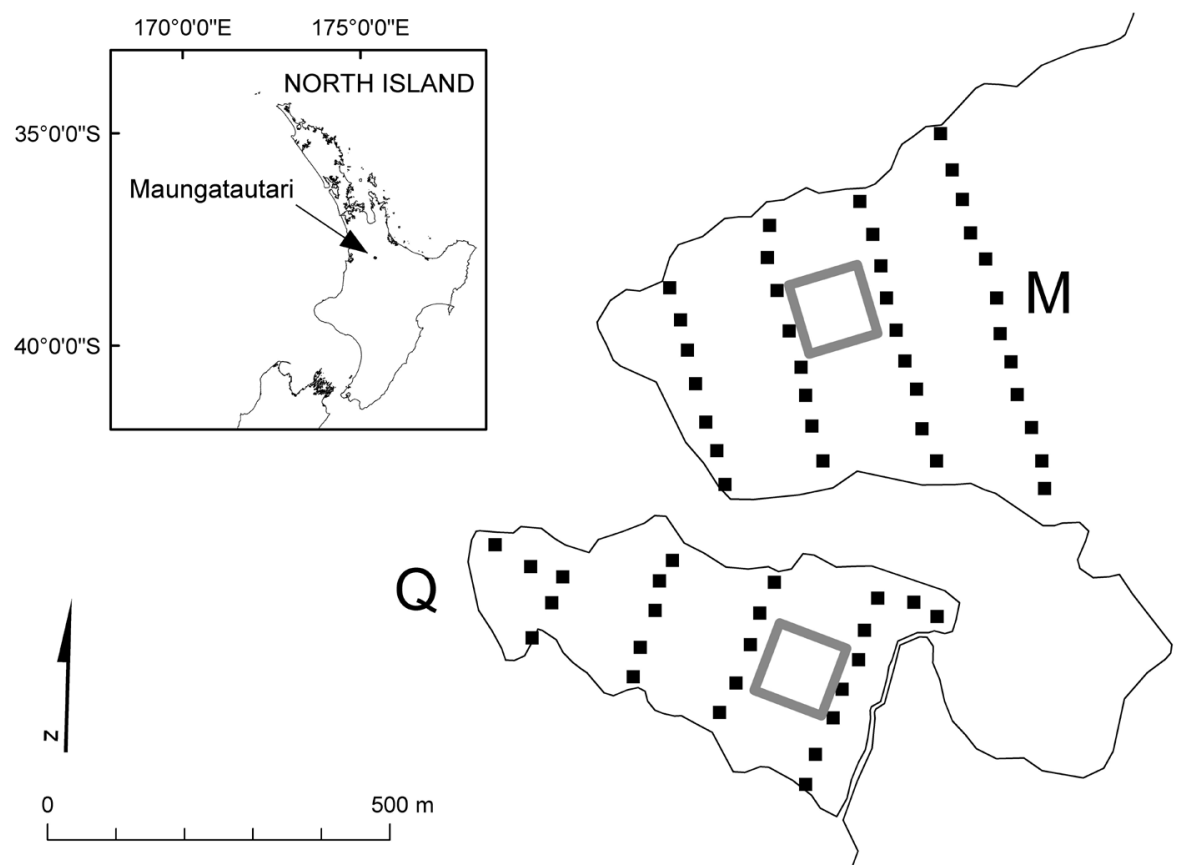

Figure 1. Locations of trapping grids (large grey squares) and tracking tunnels (small black squares) in our $\mathrm{Q}$ and $\mathrm{M}$ block study sites on the northwest edge of Maungatautari, central Waikato, North Island, New Zealand. Thin black lines indicate mammal-resistant fences surrounding 17 ha Q block and the 3400 ha area that includes M block. 
Table 1. Mouse control and initial detections on two study blocks at Maungatautari, from 2006 to 2016 . Q is a 17 ha privately owned forest block, enclosed by an independent mammal-resistant fence and adjacent to the Maungatautari biodiversity sanctuary. $\mathrm{M}$ is a 24 ha block within the main 3400 ha fenced reserve. MEIT refers to the Maungatautari Ecological Island Trust. The duration of the present study was April 2011 to February 2016.

\begin{tabular}{|c|c|c|}
\hline Block & Date & Mouse control and detection \\
\hline \multirow[t]{8}{*}{ Q } & 2006 & Independent mammal-proof fence completed \\
\hline & 2006-2008 & Mammalian pests except mice eradicated and not detected since \\
\hline & May 2008 & Mice eradicated with hand-spread toxic brodifacoum baits \\
\hline & August 2009 & Mice detected with inked footprint tracking tunnels \\
\hline & April and August 2011 & Mice tracked $>90 \%$ of tunnels (our results) \\
\hline & August 2013 & Treatment switch: mice eradicated \\
\hline & May 2014 & $\begin{array}{l}\text { Mice detected in tunnels placed by MEIT. Fence damage found and repaired, and } \\
\text { additional toxin broadcast. }\end{array}$ \\
\hline & February 2015 & $\begin{array}{l}\text { Mice detected in two tunnels (our results; } 8 \% \text { tracking rate), but none trapped and none } \\
\text { detected in subsequent sessions }\end{array}$ \\
\hline \multirow[t]{9}{*}{ M } & August 2006 & Mammal-resistant fence completed around Maungatautari biodiversity sanctuary \\
\hline & November 2006 & Eradication of mammals within the fence began. Mice probably never entirely eradicated. \\
\hline & April and August 2011 & $\begin{array}{l}\text { No mice captured in traps or detected with inked footprint tracking tunnels in M block } \\
\text { (our results) }\end{array}$ \\
\hline & November 2011 & First mouse trapped and mice detected with tracking tunnels in M block (our results) \\
\hline & February 2012 & Mouse control ceased at Maungatautari \\
\hline & August 2006 to August 2013 & $\begin{array}{l}\text { Some rat trapping and poisoning continued near } \mathrm{M} \text { block in order to kill invading ship } \\
\text { rats }\end{array}$ \\
\hline & August 2013 & $\begin{array}{l}\text { Treatment switch: poison use ceased (only rat traps used when responding to fence } \\
\text { breaches) }\end{array}$ \\
\hline & November 2014 & Toxin laid for 2 days at one fence-post south of $\mathrm{M}$ block, owing to an operational error \\
\hline & January 2016 & Toxin laid for 2 days along the fence north of $\mathrm{M}$ block, owing to an operational error \\
\hline
\end{tabular}

\section{Estimating mouse population density with spatially explicit capture-recapture}

We estimated the population density of mice (mice per hectare) with spatially explicit capture-recapture (SECR; Efford 2004; Borchers \& Efford 2008). Mice were caught in live-capture Longworth traps (NHBS, Totnes, Devon, UK). A grid of 64 traps ( 8 rows $\times 8$ columns, with $15 \mathrm{~m}$ spacing) was placed in each block (Fig. 1). Traps were baited with peanut butter and rolled oats and contained polyester fibre filling for warmth, and were checked daily in five-day capture sessions in April 2011, August 2011, and then quarterly until February 2016. Captured mice were marked with numbered metal ear-tags and released after weight, head and body length (HBL) and reproductive status were recorded. For reproductive status of females we recorded either perforate or imperforate vagina and obvious pregnancy (distended abdomen). For males we recorded testes position as scrotal or abdominal.

Mouse population density estimates were obtained by analysing the data from each quarterly capture session in each block, using the secr package (Efford 2016) in program R (R Core Team 2016). We analysed combined data from all capture sessions ( 20 per block) with $>1$ captures (M block: 17 sessions, first three sessions had $\leq 1$ capture; Q block: 10 sessions, last 10 sessions had 0 captures). Combining data from multiple sessions (White 2005) allowed us to estimate density for sessions with few (but $>1$ ) captures (i.e. many of the $\mathrm{M}$ block sessions).

We assumed that populations were closed during each 5-day trapping session (i.e. that no reproduction, mortality, immigration or emigration occurred during these periods). Spatial detection models, representing daily capture probability as a half-normal function $(g)$ of the distance between a trap and the centre of a mouse's home range (Efford 2004), were fitted to the capture data by maximising the conditional likelihood (Borchers \& Efford 2008). Two spatial detection parameters were estimated: $g_{0}$, the probability of capture (per day) in a trap located at the centre of the home range (i.e. at $0 \mathrm{~m}$ ), and spatial scale $\sigma(\mathrm{m})$. Mouse home range centres were assumed to be distributed randomly and independently in space. Mouse density in each capture session was calculated as a derived parameter; i.e. the number of captures in that session $n$ divided by the effective sampling area $a$, computed from the $g_{0}$ and $\sigma$ estimates (Borchers \& Efford 2008).

We selected a set of alternative spatial detection models of variation in the two spatial detection parameters, $g_{0}$ and $\sigma$, after comparing the performance of alternative models during the first 2 years of the study on the basis of $\mathrm{AIC}_{\mathrm{c}}$ (Burnham \& Anderson 2002). We then compared alternative models fitted to all the data from 2011 to 2016, also on the basis of $\mathrm{AIC}_{\mathrm{c}}$. In the alternative model set (Table 2), $g_{0}$ and $\sigma$ were either both constant (i.e. the null model) or were both additive functions of the block-phase combination (QH, ML, MH; QL had no captures and was excluded) and/or season (spring, summer, autumn, winter). Models in which $g_{0}$ was also an additive function of mouse weight and/or a behavioural response to capture were also tested. Two alternative types of behavioural responses to capture (Efford 2016) were considered: $b$, a permanent response in which an animal's probability of capture increased (a trap-happy response) or decreased (trap-shy) after its first capture; and $b k$, a trap-specific permanent response in which an animal became trap-happy or trap-shy in relation to a particular trap (Royle et al. 2011; Wilson et al. 2017). 
Table 2. Additive SECR models of variation in spatial detection parameters $g_{0}$ and $\sigma$, fitted to capture data of house mice at Maungatautari. At most one behavioural response to capture, $b$ or $b k$, was included in a model. The variables block-phase and season were always applied to both $g_{0}$ and $\sigma$ simultaneously, but $b, b k$ and mouse weight (at first capture) were applied to $g_{0}$ only. For discrete variables, the number of levels is given in parentheses.

\begin{tabular}{llll}
\hline Parameter & Variable & Discrete (levels) or continuous & Values \\
\hline$g_{0}$ & - & - & - (i.e. $g_{0}$ constant) \\
& block-phase & discrete (3) & QH, ML, MH \\
season & discrete (4) & spring, summer, autumn, winter \\
$b$ & discrete (2) & 0 (first capture) or 1 (captured previously) \\
$b k$ & discrete (2) & 0 (first capture) or 1 (captured previously) \\
& mouse weight & continuous & $4-28.5 \mathrm{~g}$ \\
$\sigma$ & - & - & - (i.e. $\sigma$ constant) \\
& block-phase & discrete (3) & QH, ML, MH \\
& season & discrete (4) & spring, summer, autumn, winter \\
\hline
\end{tabular}

\section{Comparing mouse demographics between block-phases QH and ML, and QH and MH}

We used mixed-effects models to compare demographic parameters of the mouse population in block-phase QH (the reference block-phase) with populations in ML and MH. Explanatory variables were block-phase $(\mathrm{QH}, \mathrm{ML}, \mathrm{MH})$, season, their interaction (where it could be fitted), and additional model-specific variables, as described below. Sampling date was fitted as a random effect (with 20 levels, up to 10 for each block-phase), to account for (1) annual variation and (2) sampling multiple mice from the same block on each date. Models were fitted in the lme4 package (Bates et al. 2015) in $\mathrm{R}$ version 3.3.0 ( $\mathrm{R}$ Core Team 2016).

An explanatory variable was considered statistically significant $(\mathrm{P}<0.05)$ if the $95 \%$ highest posterior density interval (HPDI) of its model coefficient excluded zero. We used HPDIs because the usual method of estimating 95\% confidence intervals (CI) is not straightforward for mixedeffects models. Instead, we generated 1000 estimates of each fixed-effect coefficient, representing a sample of its posterior distribution (i.e. its distribution given our data), and calculated HPDIs from these samples. We used the sim function in the arm package for R (Gelman et al. 2016) and the mcmc and HPDinterval functions in the coda package (Plummer et al. 2006). We also calculated $99 \%$ and $90 \%$ HPDIs in order to quantify $\mathrm{P}$-values relative to the respective probability levels of 0.01 and 0.1 .

Relationship between body weight and head and body length We fitted a linear mixed-effects model with the response variable $\log _{\mathrm{e}}$ (body mass) and the additional explanatory variables $\log _{\mathrm{e}}(\mathrm{HBL})$, sex, and their interactions with blockphase (QH, ML and MH, as above). The $\log _{\mathrm{e}}-\log _{\mathrm{e}}$ relationship between body mass and HBL is an indicator of small-mammal body condition (Krebs \& Singleton 1993). The explanatory variable block-phase and its interaction with $\log _{\mathrm{e}}(\mathrm{HBL})$ represent differences between block-phases (QH vs ML and $\mathrm{QH}$ vs $\mathrm{MH}$ ) in the intercept and slope, respectively, of the relationship between $\log _{\mathrm{e}}$ (body mass) and $\log _{\mathrm{e}}(\mathrm{HBL})$.

\section{Size structure as a proxy for age structure}

We assigned each mouse to one of three size classes, as a proxy for age classes, based on the $25 \%$ and $75 \%$ quantiles of body weight of all captures combined: small $(\leq 13.5 \mathrm{~g})$, medium $(>13.5 \mathrm{~g}$ and $\leq 19.5 \mathrm{~g})$, and large $(>19.5 \mathrm{~g})$. We used two generalised linear mixed-effects models for binomial data (with $\log _{\mathrm{e}}$ link functions) to investigate these multinomial data (Dobson \& Barnett 2008). We tested for block-phase differences in the probabilities that a captured small or medium mouse would be small (model 1), and a captured large or medium mouse would be large (model 2 ). The response variable in each case was the number of successes (captures of small mice for model 1 or large mice for model 2) given the number of independent trials (combined captures of medium mice and either small [model 1] or large [model 2] mice) on each capture date. An interaction between block-phase and season could not be fitted for model 1 because no small mice were captured in ML in winter.

\section{Reproductive condition}

We used two further generalised linear mixed-effects models for binomial data to test for block-phase differences in the probabilities that captured females (model 3 ) and males (model 4) would be in reproductive condition (perforate vagina or pregnant for females, scrotal testes for males). The response variable in each case was the number of successes (captures of reproductive mice) given the number of independent trials (all captures) on each capture date. Interactions between block-phase and season could not be fitted because no mice were in reproductive condition in ML in winter.

\section{Indexing mouse abundance with inked footprint tracking tunnels}

We calculated relative indices of mouse abundance in both blocks with footprint tracking based on Department of Conservation standard procedures (Gillies \& Williams 2013). We placed inked tracking tunnels (24 in Q block and 36 in M block) in lines $150 \mathrm{~m}$ apart, each with 5-12 tunnels $50 \mathrm{~m}$ apart. Because of our small block sizes, this layout differed from the recommended lines $\geq 200 \mathrm{~m}$ apart, each with 10 tunnels. Tunnels were baited with peanut butter and checked the next morning, 1-7 days prior to each quarterly 5-day capture session (above). Tracking rate (percentage of tunnels tracked by mice) was calculated for each occasion on each block. 


\section{Relationship between mouse tracking, density, and number of mice captured}

Although footprint-tracking tunnels are commonly used to index rodent abundance in New Zealand, the relationship between tracking rates and mouse population density has not often been assessed. We therefore tested whether the mousetracking rate (the percentage of inked tunnels tracked by mice) was related to mouse population density $(\mathrm{n}=17$ sessions on $\mathrm{M}$ block and 10 sessions on Q block). Because we lacked density estimates from 13 trapping sessions with $\leq 1$ mouse capture (see above), we also tested whether tracking rate was related to the number of unique mice captured in each session ( $n=20$ sessions on each block). We used separate linear models (function gls in package nlme in R; Pinheiro et al. 2017) for these two predictor variables. Block ( $M$ or $Q$ ) and its interaction with density or number of mice captured were additional predictor variables.

The models included a correlation structure (an autoregressive process of order 1) to account for temporal autocorrelation; i.e. non-independence of sequential measures (Pinheiro \& Bates 2000) within a block. The response variable was the percentage of tunnels tracked by mice in each block on each sampling date. Percentages of tunnels tracked were transformed before analysis to normalise the distribution of residuals, by expressing them as proportions and calculating the arcsine of their square-roots (Crawley 2002). Density estimates were $\log _{\mathrm{e}}$-transformed and numbers of mice captured were square-root-transformed before analysis, to linearise relationships and limit the effects of very high values.

\section{Comparing forest structure and composition between the two blocks}

The presence of vascular plant species in each of six fixedheight tiers $(<30 \mathrm{~cm}, 0.3-2 \mathrm{~m}, 2-5 \mathrm{~m}, 5-12 \mathrm{~m}, 12-20 \mathrm{~m}$, and $>20 \mathrm{~m}$ ) was recorded at 36 circular $1 \mathrm{~m}^{2}$ plots in each of the Q and M blocks in April 2015 (QL, MH). Each plot was placed $5 \mathrm{~m}$ from a tracking tunnel (Fig. 1), measured at right angles on alternating sides of each line of tunnels. In the Q block (with only 24 tracking tunnels), 12 additional plots were placed $10 \mathrm{~m}$ from other plots, on the opposite side of the line, to achieve equal numbers of plots per block.

Bray-Curtis distance was used to quantify the dissimilarity of each plot from the total species list. PERMANOVA analyses (Anderson 2001) of these Bray-Curtis dissimilarities were then used to test for differences in vegetation composition between the Q and M blocks. Separate comparisons were done for all height tiers combined and for each separate tier. In addition, to compare graphically the species composition of plots (all tiers combined) between the two blocks, a detrended correspondence analysis (DCA) ordination (Hill \& Gauch
1980) was used. These analyses were done with the adonis and decorana functions in the $\mathrm{R}$ package vegan (Oksanen et al. 2017).

\section{Results}

\section{Mouse population density}

In the best-supported model of mouse population density (i.e. the model with the lowest $\mathrm{AIC}_{\mathrm{c}}$ ), both $g_{0}$ (probability of capture of an animal in a trap at the centre of its home range) and $\sigma$ (home range width) varied as a function of mouse block-phase $(\mathrm{QH}, \mathrm{ML}$ or $\mathrm{MH})$ and season. In this model, $g_{0}$ also varied according to mouse weight and a behavioural response to capture $b$. Other models received much less support $\left(\triangle \mathrm{AIC}_{\mathrm{c}}\right.$ $\geq 11.1$; Table 3 ).

In QH, density was estimated at 9-46 mice per hectare in different capture sessions, until mice were eradicated there in August 2013. In ML, the first mouse was caught in our third capture session in November 2011, and density could not be estimated until February 2012. Thereafter, densities in $\mathrm{MH}$ increased up to $23 \mathrm{ha}^{-1}$ but never attained the highest point density estimates in $\mathrm{QH}\left(30-46 \mathrm{ha}^{-1}\right)$. Only the first $\mathrm{QH}$ density estimate differed significantly from the highest $\mathrm{MH}$ estimate, on the basis of non-overlapping 95\% CIs (QH: $44 \mathrm{ha}^{-1}, 95 \%$ CI 34-57 in April 2011; M: 23 ha $^{-1}, 17-32$ in February 2015). After February 2015, mouse density declined steadily in $\mathrm{MH}$ to $10 \mathrm{ha}^{-1}$ at the end of the study, 1 year later.

Contrasting seasonal population trajectories between blockphases

Mouse population density fluctuated seasonally in both blocks. Most years were characterised by relatively high summer or autumn (February and May) densities, winter declines (MayAugust), and gradual increases during the next breeding season (August-February; Fig. 2). There were two notable deviations from this pattern. First, in winter-spring August to November 2012, density declined in QH, but increased in ML (Fig. 2). Second, in spring-summer November 2015 to February 2016, density decreased in $\mathrm{MH}$, continuing a gradual population decline observed in $\mathrm{MH}$ throughout the final year of our study.

\section{Spatial detection parameters}

The estimated probability of capturing a mouse in a trap at the centre of its home range (parameter $g_{0}$ ) was similar in $\mathrm{QH}$ and $\mathrm{MH}$ but lower in ML (Fig. 3). Because we did not model the shapes or utilisation of individual mouse home ranges, our analysis does not yield realistic home-range size estimates. However, the average home range of mice (based on parameter $\sigma)$ was smaller in QH and $\mathrm{MH}$ than in ML, indicated by a more

Table 3. Best-supported models of spatial detection parameters for house mice captured in Longworth traps in two forest blocks at Maungatautari. $\triangle \mathrm{AIC}_{\mathrm{c}}$ gives the increase in $\mathrm{AIC}_{\mathrm{c}}$ relative to the best-supported model. Only the top three models are shown; all others had $\Delta \mathrm{AIC}_{\mathrm{c}}>44$ and weight 0 . Models are defined in Table 2.

\begin{tabular}{|c|c|c|c|c|c|}
\hline \multicolumn{2}{|l|}{ Model } & \multirow{2}{*}{ Parameters } & \multirow{2}{*}{ Log(Likelihood) } & \multirow{2}{*}{$\Delta \mathrm{AIC}_{\mathrm{c}}$} & \multirow{2}{*}{ Model weight } \\
\hline$g_{0}$ & $\sigma$ & & & & \\
\hline block-phase + season $+b+$ weight & block-phase + season & 14 & -6294.4 & 0 & 1.0 \\
\hline block-phase $+b+$ weight & block-phase & 8 & -6306.1 & 11.1 & 0.0 \\
\hline season $+b+$ weight & season & 10 & -6310.8 & 24.6 & 0.0 \\
\hline
\end{tabular}




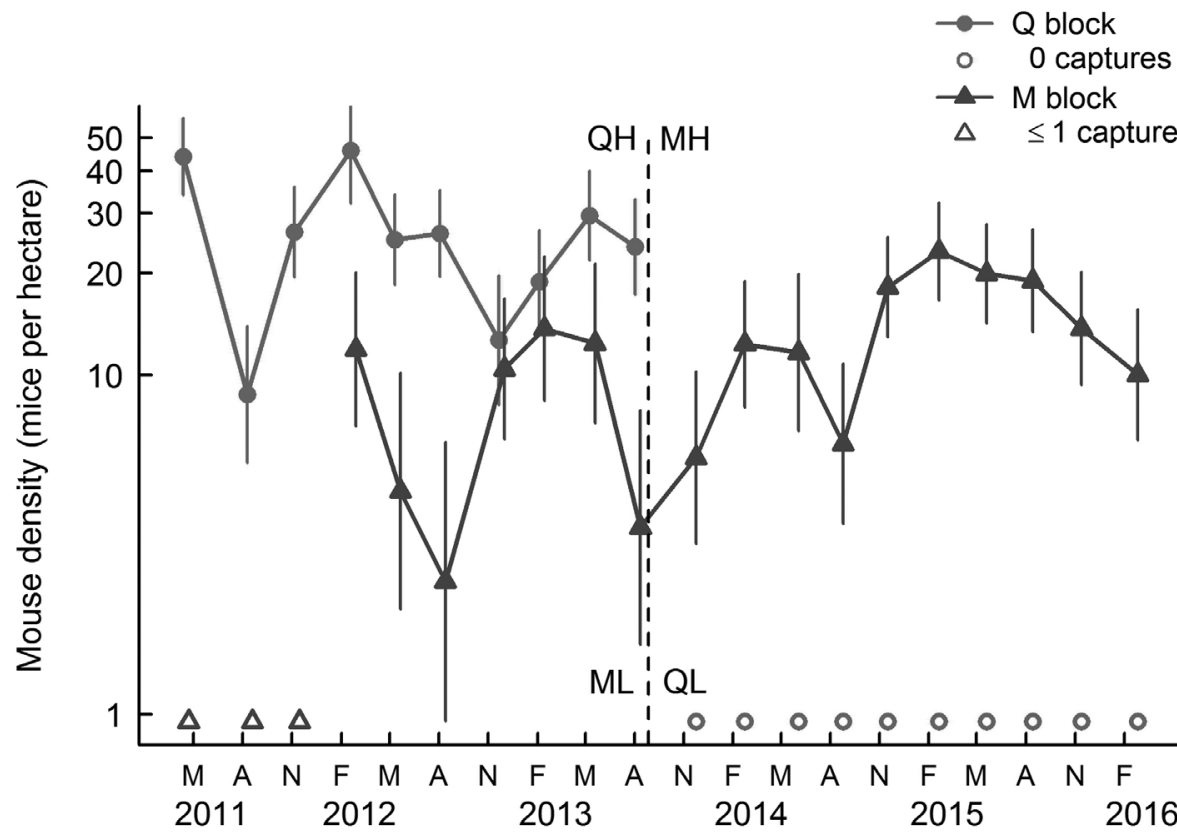

Figure 2. Estimated house mouse population density in $\mathrm{Q}$ and $\mathrm{M}$ blocks within Maungatautari Ecological Island. Vertical lines show 95\% confidence intervals. Open symbols show trapping sessions when density could not be estimated; i.e. when $\leq 1$ mice were captured in Mblock (triangles) early in the study, and when 0 mice were captured in Qblock (circles) after eradication. Timing of the treatment switch in August 2013 is shown with a dashed vertical line. Density is plotted on a logarithmic scale. QH, $\mathrm{QL}, \mathrm{MH}$, and $\mathrm{ML}$ indicate block-phase combinations, i.e. mouse densities (High, Low) that switched between blocks (Q, M) at or around August 2013.

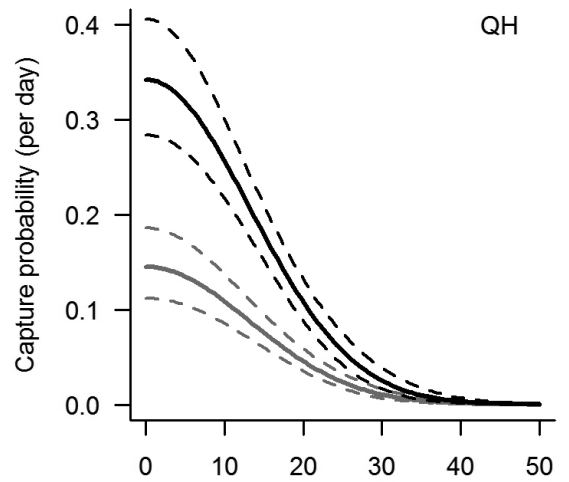

Distance from home-range centre $(\mathrm{m})$
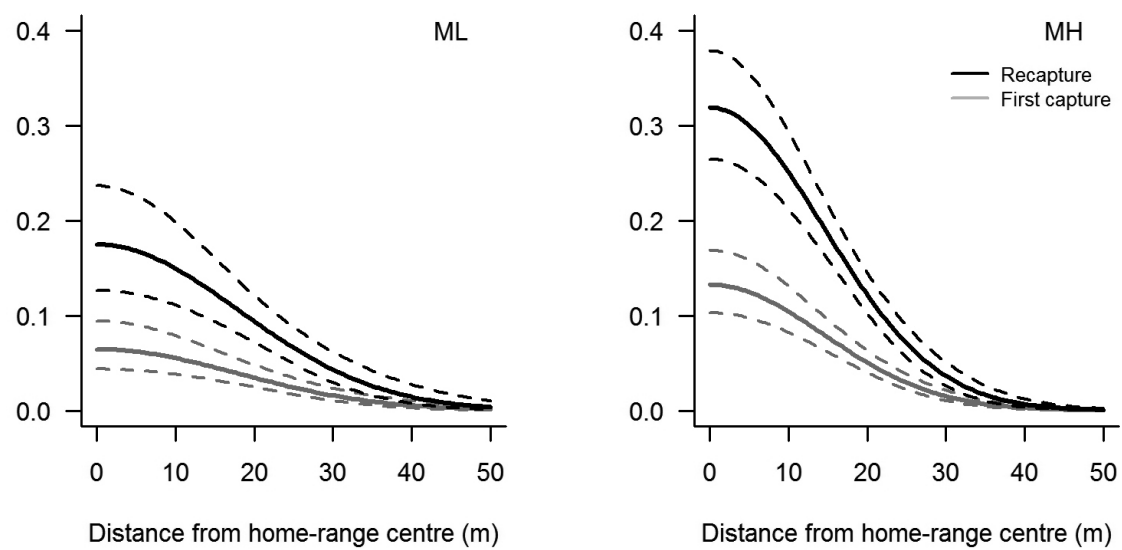

Figure 3. Modelled daily probability of capturing a mouse in a live-capture trap as a function of distance of the trap from the centre of the home range, in block-phases QH, ML and MH (i.e. block Q at high mouse population density and block M at low and high densities). Recapture probability refers to recapture during the same quarterly capture session. Capture probabilities for a $20 \mathrm{~g}$ mouse in spring are shown. Dashed lines indicate $95 \%$ confidence intervals.

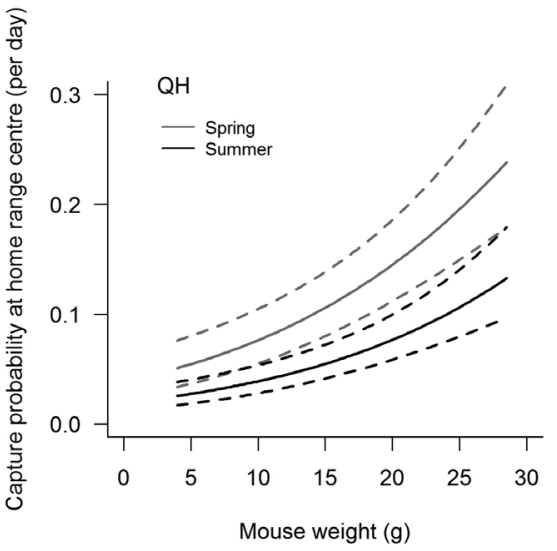

Figure 4. Modelled daily probability of capturing a mouse in a live-capture trap in the centre of its home range as a function of mouse weight. Capture probabilities for the first capture of a mouse in $\mathrm{QH}$ (block Q at high mouse population density) in spring and summer are shown. Dashed lines indicate $95 \%$ confidence intervals. rapid decline in capture probability at increasing distance from the home range centre (Fig. 3). Capture probability increased for mice recaptured during the same capture session (a traphappy response; Fig. 3), and was related positively to mouse weight (Fig. 4). Capture probability was highest in spring and lowest in summer (Fig. 4), and home range width was greater in summer than in other seasons.

\section{Comparing mouse demographics between blocks $\mathrm{QH}$ and ML, and QH and MH}

Relationship between body weight and $H B L$

There was no significant difference between $\mathrm{QH}$ and $\mathrm{ML}$ or $\mathrm{QH}$ and $\mathrm{MH}$ mouse block-phases in either the intercept or slope of the relationship between $\log _{\mathrm{e}}$ (body mass) and $\log _{\mathrm{e}}(\mathrm{HBL})$ $(\mathrm{P}>0.1)$. Body mass was positively related to HBL (both variables on the $\log _{\mathrm{e}}$ scale; $\left.\mathrm{P}<0.01\right)$. No other explanatory variables were statistically significant $(\mathrm{P}>0.05)$. 
Size structure as a proxy for age structure

On average, 34\% of large and medium mice captured in $\mathrm{QH}$ were large (>19.5 g), compared with $21 \%$ in MH (Table 4). The effect was more pronounced for males (39\% vs 18\%) than for females $(30 \%$ vs $23 \%)$. The estimated probability that a captured large or medium mouse would be large was higher in $\mathrm{QH}$ than in $\mathrm{MH}(\mathrm{P}<0.05)$ but did not differ significantly between $\mathrm{QH}$ and ML. The probability of catching a large mouse was also higher in summer than in autumn (the reference level for testing seasonal differences; $\mathrm{P}<0.05$ ).

There were no significant block-phase differences in the probability that a small or medium mouse would be small $(\leq$ $13.5 \mathrm{~g} ; \mathrm{P}>0.1)$. The probability of catching a small mouse was higher in autumn than in spring $(\mathrm{P}<0.01)$, summer $(\mathrm{P}<$ $0.05)$ and winter $(\mathrm{P}<0.01)$.

\section{Reproductive condition}

The probability of a female mouse being reproductive was higher in spring $(\mathrm{P}<0.05)$ and summer $(\mathrm{P}<0.01$; Table 4$)$ than in autumn, but there were no significant seasonal effects for males $(\mathrm{P}>0.1)$. There were no significant block-phase differences in the probability that captures of either sex would be in reproductive condition $(\mathrm{QH}$ vs $\mathrm{ML} 0.05<\mathrm{P}<0.1$ for both sexes; QH vs $\mathrm{MH}(\mathrm{P}>0.1)$.

\section{Relationship between mouse tracking, density, and number of mice captured}

Mouse tracking rates (percentage of inked footprint-tracking tunnels tracked by mice) ranged from 0 to $100 \%$, and 0 to
69 individual mice were captured in each session (Fig. 5). The percentage of tunnels with mouse tracks was positively related to the number of mice captured in each session $(\mathrm{n}=20$ sessions on each block; $t_{36}=6.1, \mathrm{P}<0.0001$ ) (both variables transformed; see Methods), but was not significantly related to mouse density ( $\mathrm{n}=17$ sessions on $\mathrm{M}$ block and 10 sessions on $\mathrm{Q}$ block, $\left.\mathrm{t}_{23}=1.5, \mathrm{P}=0.16\right)$. In both models, tracking rates did not differ significantly between the $\mathrm{Q}$ and $\mathrm{M}$ blocks, and interactions between block and mouse captures or density were not significant $\left(\mathrm{t}_{36}\right.$ or $\left.23<1.5 ; \mathrm{P}>0.16\right)$. The estimated temporal autocorrelation parameters indicating the average correlation between consecutive tracking rate observations in each block were $\varphi=0.12(95 \%$ CI $-0.28,0.48$; numbers of captures model) and $\varphi=0.53(0.004,0.823$; density model $)$.

The correlation between the two predictor variables, density and number of captures, was $r=0.95$ for the 27 sessions for which we had mouse population density estimates (i.e. sessions with $>1$ capture). Mouse tracking rates were consistently low $(0-11 \%)$ in the 13 sessions without density estimates (sessions with $\leq 1$ capture).

\section{Comparing forest structure and composition between the two blocks}

There were no significant differences in vegetation composition between $\mathrm{Q}$ and $\mathrm{M}$ blocks, in all tiers combined $\left(\mathrm{F}_{1,70}=0.85, \mathrm{P}\right.$ $=0.63$ ) or in individual tiers (for $12-20 \mathrm{~m}, \mathrm{~F}_{1,34}=1.7, \mathrm{P}=0.08$; for other tiers, $\mathrm{F}_{1,44-55}<1.4, \mathrm{P}>0.19$ ). DCA plot ordination also did not identify any difference in vegetation composition between the two blocks.

Table 4. Numbers of mice in each of three size classes, and numbers of reproductive (Repr) and non-reproductive (NR) males and females captured in Q and M blocks before the experimental treatment switch (block-phases QH and ML) and in $\mathrm{M}$ block after the treatment switch (MH) at Maungatautari from 2011 to 2016. Animals with missing weight data are omitted from the size class columns, and juveniles with unidentified sex are omitted from the reproductive status columns. The table is sorted by block-phase and season in order to show seasonal variations.

\begin{tabular}{|c|c|c|c|c|c|c|c|c|c|}
\hline \multirow{2}{*}{$\begin{array}{l}\text { Block- } \\
\text { phase }\end{array}$} & \multirow[t]{2}{*}{ Season } & \multirow[t]{2}{*}{ Date } & \multicolumn{3}{|c|}{ Size class } & \multicolumn{2}{|c|}{ Females } & \multicolumn{2}{|c|}{ Males } \\
\hline & & & Small & Medium & Large & Repr & NR & Repr & NR \\
\hline $\mathrm{QH}$ & Autumn & 12-Apr-2011 & 34 & 26 & 9 & 6 & 23 & 1 & 29 \\
\hline $\mathrm{QH}$ & Autumn & 11-May-2012 & 9 & 19 & 13 & 2 & 13 & 12 & 5 \\
\hline $\mathrm{QH}$ & Autumn & 9-Мay-2013 & 20 & 21 & 6 & 4 & 18 & 9 & 10 \\
\hline $\mathrm{QH}$ & Winter & 9-Aug-2011 & 3 & 11 & 4 & 0 & 6 & 1 & 8 \\
\hline $\mathrm{QH}$ & Winter & 3-Aug-2012 & 7 & 29 & 13 & 4 & 24 & 1 & 20 \\
\hline $\mathrm{QH}$ & Winter & 2-Aug-2013 & 10 & 26 & 5 & 1 & 22 & 0 & 18 \\
\hline $\mathrm{QH}$ & Spring & 5-Nov-2011 & 6 & 22 & 18 & 10 & 12 & 15 & 9 \\
\hline $\mathrm{QH}$ & Spring & 21-Nov-2012 & 3 & 16 & 2 & 0 & 9 & 1 & 11 \\
\hline $\mathrm{QH}$ & Summer & $18-F e b-2012$ & 18 & 16 & 14 & 8 & 15 & 2 & 11 \\
\hline $\mathrm{QH}$ & Summer & 4-Feb-2013 & 4 & 12 & 19 & 12 & 9 & 6 & 5 \\
\hline ML & Autumn & 11-May-2012 & 5 & 1 & 0 & 0 & 3 & 0 & 0 \\
\hline ML & Autumn & 9-May-2013 & 8 & 5 & 3 & 0 & 9 & 1 & 4 \\
\hline ML & Winter & 3-Aug-2012 & 0 & 4 & 0 & 0 & 2 & 0 & 2 \\
\hline ML & Winter & 2-Aug-2013 & 0 & 5 & 1 & 0 & 0 & 0 & 6 \\
\hline ML & Spring & 21-Nov-2012 & 3 & 10 & 6 & 3 & 6 & 1 & 6 \\
\hline ML & Summer & $18-F e b-2012$ & 7 & 7 & 2 & 1 & 6 & 0 & 9 \\
\hline ML & Summer & 4-Feb-2013 & 5 & 8 & 7 & 3 & 10 & 2 & 5 \\
\hline $\mathrm{MH}$ & Autumn & 24-May-2014 & 11 & 4 & 0 & 1 & 6 & 1 & 7 \\
\hline $\mathrm{MH}$ & Autumn & 10-May-2015 & 15 & 21 & 1 & 1 & 13 & 4 & 18 \\
\hline $\mathrm{MH}$ & Winter & 15-Aug-2014 & 5 & 7 & 1 & 0 & 5 & 4 & 4 \\
\hline $\mathrm{MH}$ & Winter & 4-Aug-2015 & 7 & 26 & 2 & 2 & 16 & 5 & 11 \\
\hline $\mathrm{MH}$ & Spring & 14-Nov-2013 & 1 & 7 & 3 & 1 & 6 & 2 & 2 \\
\hline $\mathrm{MH}$ & Spring & 6-Nov-2014 & 4 & 28 & 3 & 8 & 12 & 3 & 11 \\
\hline $\mathrm{MH}$ & Spring & $3-N o v-2015$ & 3 & 18 & 6 & 0 & 13 & 6 & 8 \\
\hline $\mathrm{MH}$ & Summer & $13-F e b-2014$ & 7 & 11 & 4 & 7 & 5 & 4 & 6 \\
\hline MH & Summer & $10-F e b-2015$ & 9 & 24 & 6 & 4 & 14 & 14 & 5 \\
\hline $\mathrm{MH}$ & Summer & 16-Feb-2016 & 3 & 4 & 13 & 5 & 8 & 4 & 0 \\
\hline
\end{tabular}


a)

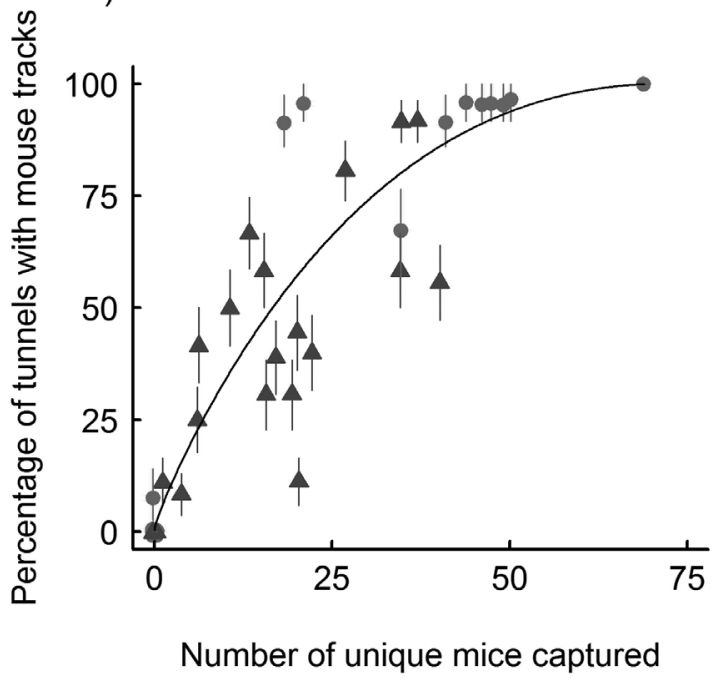

b)

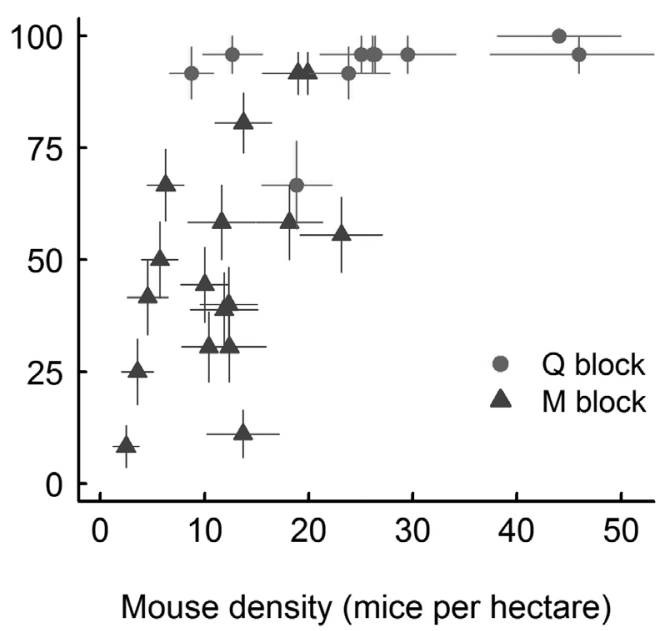

Figure 5. Mean mouse tracking rate (percentage of inked tracking tunnels tracked by mice) at the start of each trapping session, plotted as a function of (a) number of mice captured in each session and (b) estimated mouse population density in Q block and M block. The fitted curve in (a) corresponds to a model combining both blocks, as block effects were not significant. Points in (a) have been shifted by a small random amount (jittered) to reduce over-plotting. Error bars indicate standard errors.

\section{Discussion}

\section{Mouse population density and potential limiting factors}

In forests with other invasive mammals present on the New Zealand mainland, house mouse population density is usually $<6$ mice ha $^{-1}$ (Murphy 1989; Ruscoe et al. 2001, 2004; Wilson \& Lee 2010), but can reach $50 \mathrm{ha}^{-1}$ after periodic high seedfall (masting) in forests dominated by masting tree species (Ruscoe et al. 2001, 2004). The highest mouse population density estimate from the New Zealand mainland is $160 \mathrm{ha}^{-1}$ in small forest patches surrounded by pasture and rank grass in the partially fenced biodiversity sanctuary on Tawharanui Peninsula, Auckland Region (Goldwater 2007; Goldwater et al. 2012). On New Zealand islands lacking other terrestrial mammals density estimates are intermediate: up to $20 \mathrm{ha}^{-1}$ in forest (Murphy 1989; MacKay et al. 2011), $70 \mathrm{ha}^{-1}$ in grassland-shrubland (Pickard 1984; Efford 2004), and $150 \mathrm{ha}^{-1}$ in subantarctic grassland (Russell 2012). In other ecosystems worldwide, house mouse population densities have been estimated as high as $150-500 \mathrm{ha}^{-1}$ on subantarctic islands lacking other terrestrial mammals (Parker et al. 2016; McClelland et al. 2018), in fluctuating populations in arid Peru (Arana et al. 2006), and during outbreaks on grassy California hillsides (Pearson 1963). Mouse plagues in Australian wheat-growing areas can exceed $2000 \mathrm{ha}^{-1}$ (Singleton et al. 2007). Hence, the maximum mouse densities we recorded at Maungatautari (up to $46 \mathrm{ha}^{-1}$ in Q block and $23 \mathrm{ha}^{-1}$ in M block) were high when compared with most New Zealand forest ecosystems, but not with other ecosystems globally.

Although predation and interspecific competition by larger mammals may limit mouse population size (e.g. Innes et al. 1995; Witmer et al. 2007; Ruscoe et al. 2011), food supply or other factors (Pech et al. 1999; Singleton et al. 2007) may become limiting as mouse density increases following mesopredator and competitive release. This effect has been demonstrated in grassland/shrubland habitat, where lack of mouse population growth after experimental removal of higher- order mammalian predators was attributed to food limitation in locations with scarce grass seed (Norbury et al. 2013). At Maungatautari, depletion of the supply of invertebrates as food for mice when mice became abundant in our study blocks (Watts et al. 2017) may in turn have limited the mouse populations and prevented their continued increase to densities higher than those we observed.

Comparing study populations between blocks and phases: population change, spatial detection parameters and reproduction

In non-masting environments in New Zealand, mouse population density usually peaks in summer and autumn, and declines during winter (Ruscoe \& Murphy 2005). Our density estimates generally followed this pattern, with two anomalies. First, apparent density-dependent rates of population change (mouse density declining in $\mathrm{QH}$ but increasing in $\mathrm{ML}$ ) from August to November 2012 (winter-spring) were consistent with reduced food availability in QH relative to ML (discussed above). Second, declining density in MH throughout the final year of our study was also consistent with food limitation and contrasts with increasing spring-summer (NovemberFebruary) densities in other years (QH 2011/12, 2012/13; MH 2012/13, 2013/14, 2014/15). However, because our study blocks were unreplicated, we are not able to demonstrate that differences between them caused these contrasting population dynamics.

Differences between the mouse populations at high density $(\mathrm{QH}$ and $\mathrm{MH})$ and low density (ML) in the spatial detection parameters describing captures are also consistent with contrasting food availability at high and low mouse density (discussed above). Baited traps may have been more attractive to mice in higher-density populations that had depleted their invertebrate food supply (Watts et al. 2017). In addition, the apparently smaller home ranges of mice in $\mathrm{QH}$ and $\mathrm{MH}$ (based on spatial differences in capture probability) is consistent with the higher mouse densities in these block-phase combinations than in ML. 
Intra-specific competition by mice for food could have limited population growth by lowering reproduction or survival, or by increasing emigration. This process could lead to a higher reproductive rate in ML than in $\mathrm{QH}$, but we detected no differences in reproductive rate between these block-phase combinations. Survival and emigration were not measured directly.

\section{Body size and restricted emigration may lead to a 'partial fence effect'}

Because rodent population density often increases when dispersal is prevented by a fence enclosing the population, dispersal is thought to be necessary for normal rodent population regulation ('fence effect'; Krebs et al. 1969; Nelson et al. 2002; Krebs 2013). It is likely that at least some mice could emigrate over the mammal-resistant fences surrounding the 17 ha Q block and the 3400 ha main Maungatautari reserve (which contained M block), as these fences were not designed to contain mammals but to exclude them (Day \& MacGibbon 2007; Connolly et al. 2009). Small, lightweight mice may have been more able than heavy mice to climb over the fence's curved metal hood.

Restriction by the fence of adult males seeking mates ('wandering'; Wolff 2008) may in part explain the higher proportion of large mice (especially males) in $\mathrm{QH}$ than in MH. Nelson et al. (2002) found that adult male house mice emigrated from experimental enclosures at a higher rate than adult females. Other habitat differences between our study blocks do not explain mouse body size differences between $\mathrm{QH}$ and $\mathrm{MH}$, as mice in $\mathrm{QH}$ did not differ significantly in size from mice in ML, and forest composition in the two blocks is similar.

A 'partial fence effect' resulting from this restricted emigration from Q block may explain the generally higher mouse population density in $\mathrm{QH}$ than in $\mathrm{MH}$ throughout the study. In contrast, mice in Mblock could disperse throughout the larger fenced Maungatautari reserve. Immigrating mice from elsewhere in the reserve would not necessarily compensate for emigration from $\mathrm{M}$ block, owing to likely spatial variation in mouse population density (review in Krebs 2013) throughout the reserve.

\section{Relationship between tracking index and density}

Past tests of relationships between mouse tracking rates and population density had contrasting results, possibly owing to methodological differences (Nathan et al. 2013). The mouse tracking rate in inked tunnels was positively related to mouse density on Saddle Island, Hauraki Gulf, Auckland Region (Nathan et al. 2013), but not in a study in Fiordland, South Island (Ruscoe et al. 2001). Neither of these studies used standard (Gillies \& Williams 2013) tunnel spacing or placement duration.

Our study supports the use of tracking tunnels placed using standard Department of Conservation guidelines (Gillies \& Williams 2013) to roughly indicate mouse abundance, especially when populations are sparse. Tracking rates and numbers of unique mice captured were related despite the disparity in scale of the single live-trapping grid (1 ha) in each study block (a design driven by the high cost of live-trapping on multiple small grids per block), compared with the c. 20 times larger areas in which tracking tunnels were distributed. The method appeared to be most suitable for relatively sparse populations, because tracking rates approached $100 \%$ at intermediate mouse density $\left(>10-25 \mathrm{ha}^{-1}\right.$, in sessions when $>$ 20-40 mice were captured; Fig. 5). Although the relationship between tracking rates and mouse density was not statistically significant despite the high correlation between these variables, this test was relatively weak because of its smaller sample size (because density estimates were not available for sessions with $\leq 1$ captures) and higher serial correlation between sequential tracking rates.

\section{Conclusions}

Population densities of house mice after larger mammals were removed from the Maungatautari forest were similar to those observed after masting events in New Zealand beech forest and alpine grassland (Ruscoe et al. 2001, 2004; Wilson \& Lee 2010). If this mainland forest sanctuary is typical of non-masting forest locations in New Zealand, then eradication of larger mammals from these reserves may not generate the very high mouse population densities estimated on some offshore islands without other mammals (e.g. Efford 2004; Russell 2012; McClelland et al. 2018) or in forest patches surrounded by grassland on the predator-fenced Tawharanui Peninsula (Goldwater 2007).

House mouse populations are clearly often limited by predation and/or competition from other, larger pest mammals. However, the density of mice after removal of other mammals is likely to vary between locations, depending on food supply and whether any predatory mammals remain. For example, in managed urban areas it is possible that all wild and feral mammals may be removed but domestic cats remain. Therefore, given current support for Predator Free New Zealand (Russell et al. 2015), it is worth studying whether control of larger mammals in urban and rural settings leads to mouse population irruptions.

Even at moderately high density, house mice may have significant ecological impacts. In biodiversity sanctuaries they may have several additional negative consequences. First, mice may interfere with monitoring devices set to detect other species, in particular rats and mustelids, by stealing baits and obscuring footprints in tracking tunnels. Second, the extensive burrows created by house mice (Schmid-Holmes et al. 2001; Avenant \& Smith 2003) may provide conduits out of the sanctuary into adjacent mouse-free exclosures, and into the sanctuary for weasels or other predators. Finally, visible mice and their sign detract from the enjoyment by visitors and volunteers of sanctuaries that are expected to be pest-free.

\section{Acknowledgements}

We thank Bill and Sue Garland for sustained friendly permission to access their private land, and Maungatautari Ecological Island Trust staff and volunteers for access to land and for other collaborations. In particular, Maungatautari staff undertook and maintained the 2013 eradication of mice in Q block. Thanks to Kevin Collins, Alan Saunders, and Dave Byers (all Waikato Regional Council), and to Jack Craw (Auckland Council), for funding and other support. Lucy Bridgman, Susan Emmitt and Danny Thornburrow gave field assistance, and Norman Mason analysed the forest composition data. We are also grateful to Jamie MacKay, Des Smith, Bill Lee, Ray Prebble and an anonymous reviewer for comments that improved the 
manuscript. This research was funded by the Strategic Science Investment Fund for Crown Research Institutes from the Ministry of Business, Innovation and Employment's Science and Innovation group, and by Waikato Regional Council.

\section{References}

Anderson MJ 2001. Permutation tests for univariate or multivariate analysis of variance and regression. Canadian Journal of Fisheries and Aquatic Sciences 58: 626-639.

Angel A, Wanless RM, Cooper J 2009. Review of impacts of the introduced house mouse on islands in the Southern Ocean: are mice equivalent to rats? Biological Invasions 11: 1743-1754.

Arana M, Ruiz-Luna ML, Maria SS, Ramirez O 2006. Population fluctuations of the house mouse in a Peruvian loma and the functional response of burrowing owls. Austral Ecology 31: 956-963.

Auffray JC, Vanlerberghe F, Brittondavidian J 1990. The house mouse progression in Eurasia - a paleontological and archaeozoological approach. Biological Journal of the Linnean Society 41: 13-25.

Avenant NL, Smith VR 2003. The microenvironment of house mice on Marion Island (sub-Antarctic). Polar Biology 26: $129-141$.

Bates D, Machler M, Bolker BM, Walker SC 2015. Fitting linear mixed-effects models using lme4. Journal of Statistical Software 67: 1-48.

Borchers DL, Efford MG 2008. Spatially explicit maximum likelihood methods for capture-recapture studies. Biometrics 64: 377-385.

Bridgman LJ, Innes J, Gillies C, Fitzgerald NB, Miller S, King CM 2013. Do ship rats display predatory behaviour towards house mice? Animal Behaviour 86: 257-268.

Bronson FH 1979. Reproductive ecology of the house mouse. Quarterly Review of Biology 54: 265-299.

Brown KP, Moller H, Innes J, Alterio N 1996. Calibration of tunnel tracking rates to estimate relative abundance of ship rats (Rattus rattus) and mice (Mus musculus) in a New Zealand forest. New Zealand Journal of Ecology 20: 271-275.

Burnham KP, Anderson DR 2002. Model selection and multimodel inference: a practical information theoretic approach. New York, Springer-Verlag. 353 p.

Caut S, Casanovas JG, Virgos E, Lozano J, Witmer GW, Courchamp F 2007. Rats dying for mice: modelling the competitor release effect. Austral Ecology 32: 858-868.

Choquenot D, Ruscoe WA 2000. Mouse population eruptions in New Zealand forests: the role of population density and seedfall. Journal of Animal Ecology 69: 1058-1070.

Connolly TA, Day TD, King CM 2009. Estimating the potential for reinvasion by mammalian pests through pest-exclusion fencing. Wildlife Research 36: 410-421.

Courchamp F, Langlais M, Sugihara G 1999. Cats protecting birds: modelling the mesopredator release effect. Journal of Animal Ecology 68: 282-292.

Courchamp F, Chapuis JL, Pascal M 2003. Mammal invaders on islands: impact, control and control impact. Biological Reviews 78: 347-383.

Crawley MJ 2002. Statistical computing: an introduction to data analysis using S-Plus. Chichester, Wiley. $761 \mathrm{p}$.

Cuthbert R, Hilton G 2004. Introduced house mice Mus musculus: a significant predator of threatened and endemic birds on Gough Island, South Atlantic Ocean? Biological Conservation 117: 483-489.

Day T, MacGibbon R 2007. Multiple-species exclusion fencing and technology for mainland sites. In: Witmer GW, Pitt WC, Fagerstone KA eds. Managing vertebrate invasive species. Proceedings of an International Symposium. Pp. 418-433.

Dobson AJ, Barnett AG 2008. An introduction to generalised linear models, 3rd edn. Boca Raton, Chapman \& Hall. $307 \mathrm{p}$.

Efford M 2004. Density estimation in live-trapping studies. Oikos 106: 598-610.

Efford MG 2016. secr: spatially explicit capture-recapture models. R package version 2.10.2. http://CRAN.R-project. org/package $=$ secr $($ accessed 28 April 2016).

Gelman A, Su Y-S, Yajima M, Hill J, Pittau MG, Kerman J, Zheng T, Dorie V. arm: data analysis using regression and multilevel/hierarchical models. R package version 1.9-3. http://CRAN.R-project.org/package=arm (accessed 29 November 2017).

Gillies CA, Williams D 2013. DOC tracking tunnel guide v2.5.2: using tracking tunnels to monitor rodents and mustelids. Hamilton, NZ, Department of Conservation, Science \& Capability Group. http://www.doc.govt.nz (accessed 15 May 2017).

Goldwater N 2007. Ecology of house mice within the Tawharanui Open Sanctuary. Unpublished MSc thesis, University of Auckland, Auckland, New Zealand.

Goldwater N, Perry GLW, Clout MN 2012. Responses of house mice to the removal of mammalian predators and competitors. Austral Ecology 37: 971-979.

Harper GA, Cabrera LF 2010. Response of mice (Mus musculus) to the removal of black rats (Rattus rattus) in arid forest on Santa Cruz Island, Galapagos. Biological Invasions 12: 1449-1452.

Hill MO, Gauch HG Jr. 1980. Detrended correspondence analysis: an improved ordination technique. Vegetatio 42: 47-58

Innes J, Warburton B, Williams D, Speed H, Bradfield P 1995. Large-scale poisoning of ship rats (Rattus rattus) in indigenous forests of the North Island, New Zealand. New Zealand Journal of Ecology 19: 5-17.

Innes J, Lee WG, Burns B, Campbell-Hunt C, Watts C, Phipps $\mathrm{H}$, Stephens T 2012. Role of predator-proof fences in restoring New Zealand's biodiversity: a response to Scofield et al. (2011). New Zealand Journal of Ecology 36: 232-238.

Ji WH, Veitch CR, Craig JL 1999. An evaluation of the efficiency of rodent trapping methods: The effect of trap arrangement, cover type, and bait. New Zealand Journal of Ecology 23: 45-51.

Jones AG, Chown SL, Gaston KJ 2003. Introduced house mice as a conservation concern on Gough Island. Biodiversity and Conservation 12: 2107-2119.

King CM 1983. The relationships between beech (Nothofagus sp.) seedfall and populations of mice (Mus musculus), and the demographic and dietary responses of stoats (Mustela erminea), in three New Zealand forests. Journal of Animal Ecology 52: 141-166.

King CM ed. 2005. The handbook of New Zealand mammals. 2nd edn. Melbourne, Oxford University Press. 610 p.

King CM 2016. How genetics, history and geography limit potential explanations of invasions by house mice $M u s$ musculus in New Zealand. Biological Invasions 18: 
$1533-1550$

Krebs CJ 2013. Population fluctuations in rodents. Chicago and London, The University of Chicago Press. 306 p.

Krebs CJ, Singleton GR 1993. Indexes of condition for small mammals. Australian Journal of Zoology 41: 317-323.

Krebs CJ, Keller BL, Tamarin RH 1969. Microtus population biology: demographic changes in fluctuating populations of $M$. ochrogaster and M. pennsylvanicus in Southern Indiana. Ecology 50: 587-607.

Krebs CJ, Kenney AJ, Singleton GR, Mutze G, Pech RP, Brown PR, Davis SA 2004. Can outbreaks of house mice in south-eastern Australia be predicted by weather models? Wildlife Research 31: 465-474.

MacKay JWB, Murphy EC, Anderson SH, Russell JC, Hauber ME, Wilson DJ, Clout MN 2011. A successful mouse eradication explained by site-specific population data. In: Veitch CR, Clout MN, Towns DR eds. Island invasives: eradication and management. Gland, IUCN (International Union for Conservation of Nature). Pp. 363-371.

McClelland GTW, Altwegg R, Van Aarde RJ, Ferreira S, Burger AE, Chown SL 2018. Climate change leads to increasing population density and impacts of a key island invader. Ecological Applications 28: 212-224.

McQueen S, Lawrence B 2008. Diet of ship rats following a mast event in beech (Nothofagus spp.) forest. New Zealand Journal of Ecology 32: 214-218.

Murphy EC 1989. The demography of an island and mainland population of house mice in the Marlborough Sounds, New Zealand. Unpublished PhD thesis, Victoria University of Wellington, New Zealand.

Myers JH, SimberloffD, Kuris AM, Carey JR 2000. Eradication revisited: dealing with exotic species. Trends in Ecology \& Evolution 15: 316-320.

Nathan HW, Clout MN, Murphy EC, MacKay JWB 2013. Strategies for detection of house mice on a recently invaded island. New Zealand Journal of Ecology 37: 26-32.

Nelson AR, Johnson CL, Matter WJ, Mannan RW 2002. Tests of emigration in small mammals under experimental conditions. Canadian Journal of Zoology 80: 2056-2060.

Newman DG 1994. Effects of a mouse, Mus musculus, eradication programme and habitat change on lizard populations of Mana Island, New Zealand, with special reference to McGregor's skink, Cyclodina macgregori. New Zealand Journal of Zoology 21: 443-456.

Nicholls JL 1967. Ecological survey of New Zealand's indigenous forests. Sheet N75 Arapuni. Rotorua, Forest Research Institute, New Zealand Forest Service, New Zealand.

Norbury G, Byrom A, Pech R, Smith J, Clarke D, Anderson $\mathrm{D}$, Forrester G 2013. Invasive mammals and habitat modification interact to generate unforeseen outcomes for indigenous fauna. Ecological Applications 23: 1707-1721.

Norbury G, van den Munckhof M, Neitzel S, Hutcheon A, Reardon J, Ludwig K 2014. Impacts of invasive house mice on post-release survival of translocated lizards. New Zealand Journal of Ecology 38: 322-327.

O'Boyle M 1974. Rats and mice together: the predatory nature of the rat's mouse-killing response. Psychological Bulletin 81: 261-269.

O'Donnell CFJ, Weston KA, Monks JM 2017. Impacts of introduced mammalian predators on New Zealand's alpine fauna. New Zealand Journal of Zoology 41: 1-22.

Oksanen J, Blanchet FG, Friendly M, Kindt R, Legendre P, McGlinn D, Minchin PR, O’Hara RB, Simpson GL,
Solymos P, Stevens MHH, Szoecs E, Wagner H 2017. vegan: Community Ecology Package. R package version 2.4-4. https://CRAN.R-project.org/package=vegan (accessed 29 November 2017).

Parker GC, Black A, Rexer-Huber K, Sommer E, Cuthbert RJ 2016. Low population density and biology of an island population of house mice Mus musculus on South Georgia. Polar Biology 39: 1175-1181.

Pearson OP 1963. History of two local outbreaks of feral house mice. Ecology 44(3): 540-549.

Pech RP, Hood GM, Singleton GR, Salmon E, Forrester RI, Brown PR. 1999. Models for predicting plagues of house mice (Mus domesticus) in Australia. In: Singleton GR, Hinds LA, Leirs H, Zhang Z eds. Ecologically-based management of rodent pests. Canberra, Australian Centre for International Agricultural Research. Pp. 81-112.

Pickard CR 1984. The population ecology of the house mouse (Mus musculus) on Mana Island. Unpublished MSc thesis, Victoria University of Wellington, New Zealand.

Pinheiro JC, Bates DM 2000. Mixed-effects modelling in S and S-PLUS. New York, Springer-Verlag. 528 p.

Pinheiro J, Bates D, DebRoy S, Sarkar D, R Core Team 2017. nlme: linear and nonlinear mixed effects models. R package version 3.1-131. https://CRAN.R-project.org/ package $=$ nlme $($ accessed 29 November 2017).

Plummer M, Best N, Cowles K, Vines K 2006. coda: convergence diagnosis and output analysis for MCMC. R News 6: 7-11.

R Core Team 2016. R: a language and environment for statistical computing. Vienna, Austria, R Foundation for Statistical Computing. http://www.R-project.org/.

Rayner MJ, Hauber ME, Imber MJ, Stamp RK, Clout MN 2007. Spatial heterogeneity of mesopredator release within an oceanic island system. Proceedings of the National Academy of Sciences 104: 20862-20865.

Ritchie EG, Johnson CN 2009. Predator interactions, mesopredator release and biodiversity conservation. Ecology Letters 12: 982-998.

Ritchie EG, Elmhagen B, Glen AS, Letnic M, Ludwig G, McDonald RA 2012. Ecosystem restoration with teeth: what role for predators? Trends in Ecology \& Evolution 27: 265-271.

Royle JA, Magoun AJ, Gardner B, Valkenburg P, Lowell RE 2011. Density estimation in a wolverine population using spatial capture-recapture models. Journal of Wildlife Management 75: 604-611.

Ruscoe WA, Murphy EC 2005. House mouse. In: King CM ed. The handbook of New Zealand mammals. 2nd edn. Melbourne, Oxford University Press. Pp. 203-221.

Ruscoe WA, Goldsmith R, Choquenot D 2001. A comparison of population estimates and abundance indices for house mice inhabiting beech forests in New Zealand. Wildlife Research 28: 173-178.

Ruscoe W, Wilson D, McElrea L, McElrea G, Richardson SJ 2004. A house mouse (Mus musculus) population eruption in response to rimu (Dacrydium cupressinum) seedfall in southern New Zealand. New Zealand Journal of Ecology 28: 259-265.

Ruscoe WA, Ramsey DSL, Pech RP, Sweetapple PJ, Yockney I, Barron MC, Perry M, Nugent G, Carran R, Warne R, Brausch C, Duncan RP2011. Unexpected consequences of control: competitive vs. predator release in a four-species assemblage of invasive mammals. Ecology Letters 14: 1035-1042. 
Russell JC 2012. Spatio-temporal patterns of introduced mice and invertebrates on Antipodes Island. Polar Biology 35: 1187-1195.

Russell JC, Innes JG, Brown PH, Byrom AE 2015. Predatorfree New Zealand: Conservation country. Bioscience 65: 520-525.

Schmid-Holmes S, Drickamer LC, Robinson AS, Gillie LL 2001. Burrows and burrow-cleaning behaviour of house mice (Mus musculus domesticus). American Midland Naturalist 146: 53-62.

Simberloff D 2009. Rats are not the only introduced rodents producing ecosystem impacts on islands. Biological Invasions 11: 1735-1742.

Singleton GR, Tann CR, Krebs CJ 2007. Landscape ecology of house mouse outbreaks in south-eastern Australia. Journal of Applied Ecology 44: 644-652.

Smith RK, Pullin AS, Stewart GB, Sutherland WJ 2010. Effectiveness of predator removal for enhancing bird populations. Conservation Biology 24: 820-829.

Soulé ME, Bolger DT, Alberts AC, Wright J, Sorice M, Hill S 1988. Reconstructed dynamics of rapid extinctions of chaparral-requiring birds in urban habitat islands. Conservation Biology 2: 75-92.

Speedy C, Day T, Innes J 2007. Pest eradication technology - the critical partner to pest exclusion technology: the Maungatautari experience. In: Witmer GW, Pitt WC, Fagerstone KA eds. Managing vertebrate invasive species: proceedings of an International Symposium. Pp. 115-126.

Tennyson AJD, Taylor GA 1999. History, fauna and flora of Te Haupa (Saddle) Island, Hauraki Gulf. Tane 37: 69-89.

Trewby ID, Wilson GJ, Delahay RJ, Walker N, Young R, Davison J, Cheeseman C, Robertson PA, Gorman ML, McDonald RA 2008. Experimental evidence of competitive release in sympatric carnivores. Biology Letters 4: 170-172.

Received 19 December 2017; accepted 9 May 2018

Editorial board member: Des Smith
Watts C, Innes J, Wilson D, Fitzgerald N, Bartlam S, Thornburrow D, Smale M, Barker G 2017. Impacts of mice alone on biodiversity: final report of a Waikato field trial. Hamilton, Landcare Research. 43 p.

White GC 2005. Correcting wildlife counts using detection probabilities. Wildlife Research 32: 211-216.

Wilmshurst JM, Anderson AJ, Higham TFG, Worthy TH 2008. Dating the late prehistoric dispersal of Polynesians to New Zealand using the commensal Pacific rat. Proceedings of the National Academy of Sciences of the United States of America 105: 7676-7680.

Wilson DJ, Lee WG 2010. Primary and secondary resource pulses in an alpine ecosystem: snow tussock grass (Chionochloa spp.) flowering and house mouse (Mus musculus) populations in New Zealand. Wildlife Research 37: 89-10.

Wilson DJ, Mulvey RL, Clarke DA, Reardon JT 2017. Assessing and comparing population densities and indices of skinks under three predator management regimes. New Zealand Journal of Ecology 41: 84-97.

Witmer GW, Boyd F, Hillis-Starr Z 2007. The successful eradication of introduced roof rats (Rattus rattus) from Buck Island using diphacinone, followed by an irruption of house mice (Mus musculus). Wildlife Research 34: $108-115$.

Wolff JO 2008. Alternative reproductive tactics in nonprimate male mammals. In: Oliveira RF, Taborsky M, Brockmann HJ eds. Alternative reproductive tactics: an integrative approach. Cambridge, Cambridge University Press. Pp. 356-372.

Zavaleta ES, Hobbs RJ, Mooney HA 2001. Viewing invasive species removal in a whole-ecosystem context. Trends in Ecology and Evolution 16: 454-459. 